\author{
Janez Vodičar \\ University of Ljublana, Slovenia
}

\title{
From Listening to Hearing the Message
}

\begin{abstract}
Evangelizing is searching for an appropriate language to hand on Revelation. Demonstrated is a possible use of linguistic theories and educationally-developmental understandings of Vigotsky, to reach an increasingly isolated human. A selfcentered human being (autologous) has a difficult time understanding others and is thus becoming more empty-like he has no purpose. Evangelizing, which brings Revelation, a language of Another, becomes necessary to free the modern human for dectological sphere. Even though authology has become a part of approaches of evangelization, pastoral care has to become more dectological. The possibility of becoming open to transcendental in immanence of a subject is shown through three types of passivity in the philosophy of P. Ricoeur. Thus we see compatibility of new methods of evangelizing with the old ones. The best solution for modern evangelizing is shown in the community of the Church, which contains all of the necessary language for accepting the revelation of God as well as our neighbor. This way our God and our neighbor will be heard in the world, which firmly stands by freedom and autonomy.
\end{abstract}

\section{Keywords}

Evangelizing, Revelation, language, autology, dectology, community, Church.

\section{Freedom - an Obstacle to Evangelization?}

Today we can assume for the majority of the Christian world that, "Increasingly, faith is no longer something people inherit but something they seek"1. Modern evangelization can no longer build on tradition, but on addressing each individual, through a personal experience. The danger for this

\footnotetext{
1 W. A. Nord, Does God make a differnce?, Oxford 2010, Oxford University Press, p. 15.
} 
anthropological basis of evangelization is that in its foundation we miss the purpose of evangelization. "The main criticism raised against this model was that it would reduce faith to something purely ,human', to merely reflecting common human values. The element of mystery, the idea of transcendence, the ,distinct otherness' of the faith would be totally absorbed by what was ,understandable' from the sole standpoint of human experience" 2 . This kind of approach would also be contradicting the requirement of Second Vatican Council, "The obedience of faith" is to be given to God who reveals, an obedience by which man commits his whole self freely to God, offering the full submission of intellect and will to God who reveals," and freely assenting to the truth revealed by Him"'.

A quick solution would be to return to tradition, the faith, which spurns from obedience. "For some this paradigm sounds very attractive but for many others and certainly for many catechists, it is not at all appealing, partly because the link with a person's life experiences is far from explicit"4.

On the other hand, anything connected with orders, commandments, detracts people today. We want to be free and responsible, as J.P. Sartre would put it, independent authors of our own existence ${ }^{5}$. If Sartre denies God, modern believer seems to have more of a difficulty accepting God's transcendence, something different than himself ${ }^{6}$, which is the basic condition for 'obedience of faith'. We could say that there is a slight problem of understanding, approach, or language, but it points to a wider anthropological problem, which we must understand today if we want to proclaim God, in whom a Christian is supposed to believe and find salvation through him?

2 A. Dillen and D. Pollefeyt, Catechesis Inside Out. A Hermeneutical Model for Catechesis in Parishes, "The Person and the Challenges" 1 (2011) 1, p. 154.

3 Dei Verbum (Dogmatic Constitution on Divine Revelation) 5.

4 A. Dillen and D. Pollefeyt, Catechesis Inside Out. A Hermeneutical Model for Catechesis in Parishes, p. 156.

5 See J. P. Sartre, Izbrani filozofski spisi, Ljubljana 1968, Cankarjeva založba, p. 188.

6 See L. Ferry, L'Homme-Dieu, Paris 1996, Grasset \& Fasquelle. Ferry believes that with humanization of society, there is a new incarnation of deity: man becomes God, which he proves with numerous facts of modern life. This, to him, is the new way to a more 'humane' spirituality, the way from transcendence to immanence.

7 Die österreichischen Bischöfe, Verkündigung und neue Evangelisierung in der Welt von heute, Wien 2012, Österreichische Bischofskonferenz, p. 13. The bishops' conference of Austria, in its new pastoral plan, took the sense of freedom of the modern man, as the starting point for the new evangelization. Thus evangelization must also choose the way of 'free choice', because this is in accordance with the fundamental Christian calling to freedom and responsibility before God. 
Faith, which saves a Christian, is life in infinite love of the Holy Trinity. When Bernard Sesboüé, like Austrian bishops, tries to invite ${ }^{8}$ the modern man to faith, he faces a problem - modern man no longer understands the language about Trinitarian God. Therefore he says it has to start with the human being and his experience 9 . However, it will be difficult for the 'human' side of language alone to bring us to understanding and accepting revelation in its full capacity for salvation. Especially, if we believe the claims that modern man is becoming increasingly self-focused and think of himslef as the only source of truth. "The worldwide political consolidation, economic globalization, the democratization of society and education, open communication and intercultural contact, scientific and technological innovations lead to a different kind of self-consciousness as a new basis for personal autonomy"10. Man is no longer ready to accept outside authority, but wants to find truth on his own. Traditional separation in immanent and transcendent is becoming increasingly difficult. Especially because the latter doesn't speak to modern humans as much as it used to, despite the fact that in the Church teaching it represents the fundamental orientation of evangelization. "A double shift, at the anthropological and at the theological levels, continues to cause confusion and obstinate misunderstandings"11. At the same time from a wider, anthropological point of view, the worst thing is that humans remain caught in themselves and are no longer open for dialogue which is a basic prerequisite for understanding the vastness of Divine $^{12}$.

8 See B. Sesboüé, Croire. Invitation à la foi catholique pour les femmes et les hommes du XXI. siècle, Paris 1999, Droguet \& Ardant. Main title 'To Believe' also has a subtitle 'Invitation to Catholic Faith for Women and Men of the XXI. Century'.

9 B. Sesboüé, Croire. Invitation à la foi catholique pour les femmes et les hommes du XXI. siècle, op. cit., p. 19.

${ }^{10} \mathrm{H}$. Lombaerts and D. Pollefeyt, The Emergence of Hermeneutics in Religious Education Theories: An Overview, in: H. Lombaerts in D. Pollefeyt (eds.), Hermeneutics and Religious Education, Leuven 2004, Leuven University Press, p. 4.

${ }^{11}$ H. Lombaerts and D. Pollefeyt, The Emergence of Hermeneutics in Religious Education Theories, op. cit., p. 10.

${ }_{12}$ M. Buber, Božji mrk, Celje 2004, Mohorjeva družba, p. 99. "With God we can only have a me-you relationship, because we cannot - in an unconditional contrast to everything else that lives - have an object(ive) view about him; even seeing doesn't bring us objective reflection, because whoever tries to, without the full me-you relationship, clinging to the afterimage, has already lost the vision". 


\section{Only Methodological Solutions to Evangelization?}

Man's aspiration for freedom could be the reason why we search for a way to accept the Revelation going in the direction from human beings to God, which is happening in many new methods of religious education and evangelization ${ }^{13}$. Experience has become a magic word in this. Of course it is not about experiencing God in one's life, but the experience of a human, who is filled with more or less affirming and predicted results. In this onedirectional focus on human experience we would neglect a basic dimension of Christianity, and Judaism before that: revelation - God enters our world first and speaks to $\mathrm{us}^{14}$. This is likely not meant like some baroque paintings depicting Evangelists, where the man is simply listening and trying to understand what someone is whispering in his ear. Evangelizing is always fundamentally focused on life. Therefore it stands that in pastoral work we need something more than just understanding raw dogmatic principles. Even in relation to the Holy Bible we are using a sort of hermeneutic approach, because the word of God should lead us to faith, which should incarnate in our every-day life, and just understanding is not enough for that ${ }^{15}$.

Today, striving to adapt the Revelation to people in a way that they can understand it, often leads to mere explaining, true catechesis, however, must always prepare people to allow God to speak to them about himself, and not just to have people talking about $\operatorname{God}^{16}$. Sesboüe is also aware of that, which is why he sees the door, which would open modern man's way to revelation, in

${ }^{13}$ Numerous handbooks, through their titles alone, show their intention to emanate from man, as they try to lead him to an experience of religious; this is especially obvious in so called wholesome methods. See Ganzheitliche Methoden im Religionsunterricht, L. Rendle (ed.), München 2007, Kösel-Verlag; H. Mendl, Religion erleben, München 2008, Kösel-Verlag.

14 Jn 1: 16-18.

15 The above-mentioned pastoral guidance of Austrian bishops tries to use the experience of the two disciples on their way to Emmaus. In this guidance, the evangelizer is compared to a companion, who takes the experience seriously, and is led to the discovery of Christ and his salvation. This companion can be a group or an individual, who is open to somebody else's experience, and can use this experience to open people to the message (p.16). Second Vatican Council takes a similar position, "Through this revelation, therefore, the invisible God out of the abundance of His love speaks to men as friends and lives among them, so that He may invite and take them into fellowship with Himself". Dei Verbum (Dogmatic Constitution on Divine Revelation) 2.

${ }^{16}$ See S. Curro, La parole s'est faite chair... et la chair parle sur le langage religieux en relation avec la catéchèse, Malta 2012: EEC Congrès (manuscript), p. 9. 
the research of language about God. In his work, before he starts explaining the creed, he gives an example of students who, at the beginning of the twentieth century in a French Catholic school, had to listen to a homily. The more the homilist tried to use different analogies to explain the Trinitarian God, the less his students listened. After the Mass, one of the students was making fun of what was said in the homily. The teacher, who heard the student's remarks, did not respond with educational threats, but he stepped to the young man and said to him, "Do you not know that nothing is more difficult than talking about God?" The young man thought about this rhetorical question for a while, and continued thinking about it his whole life, because this was the moment when he realized a twofold mystery: the mystery of man, and the mystery of God. The young man grew up to be the important theologian Henri de Lubac. In that moment, young Henri accepted his life vocation: to help man understand the mystery of how it is even possible for a finite man to talk, and actually say something, about the infinite God ${ }^{17}$.

General directory for catechesis, knowing how quickly we can avoid this difficult task, requires that catechesis, "needs to announce the essential mysteries of Christianity, promoting the Trinitarian experience of life in Christ as the center of the life of faith" ${ }^{\text {"1 }}$. The prologue of the Gospel of John is the basis for this catechetical approach, "The Word became flesh and made his dwelling among us"19. Keeping in mind that Christ, as the biggest revelation of God, incarnated in a specific culture and a specific time in history, then it is imperative that the modern message keeps trying to 'incarnate' in a specific language of a specific culture in a specific time in history. Therefore catechesis should be far from ignoring certain methods that can present faith in a wholesome way to modern man, and that use individual's autonomy as a starting point. Just as at Pentecost when each person heard the message in their own language ${ }^{20}$, today we have to speak in a language that people understand in the process of catechesis or evangelization. In this process we cannot forget that the main goal of using the 'correct' language is a life in faith, hope, and love. Language must become a matter of faith, not by just speaking the words

${ }^{17}$ See B. Sesboüé, Croire. Invitation à la foi catholique pour les femmes et les hommes du XXI. siècle, Paris 1999, Droguet \& Ardant, p. 57-58.

${ }^{18}$ General directory for catechesis, 33.

19 Jn 1:14.

${ }^{20}$ Acts 2:6. 
in faith, but by living in faith and witness to others about it. General directory for catechesis requires something similar, "The definitive aim of catechesis is to put people not only in touch, but also in communion and intimacy, with Jesus Christ" ${ }^{21}$. It is familiarity that is the fundamental dimension of language. A man, who cannot understand another man, cannot answer him. Therefore creating a language which will open and sustain a dialogue with God as well as with brothers and sisters in faith is the fundamental mission of catechesis and wholesome evangelization. It seems that we are facing a similar dilemma as the first Church, when they had to translate from 'Hebrew' language about God into the 'Greek' language ${ }^{22}$. The Church does not so much speak to the deaf world, but its language has emptied. There is no more living relationship, the foundational mystery of the Holy Trinity in it. Therefore it is not so much about a crisis of proper or improper words, but more about the crisis of the experience of faith itself. "If we lose the words for our faith, we have lost access to faith as well; we no longer live from its experience" ${ }^{23}$. The real new evangelization, which will bring language that is understandable to modern man, has to surpass the questions of methodology and terminology; it has to become the question of existence or nonexistence of the Church and its community living in connection with God who revealed himself fully in Jesus Christ. If we want to find a language, or better still languages, which will primarily speak to believers, and secondarily have effective catechetical value for interpersonal relationship, we have to rethink the nature of Christian community living, individual believers, and what effectively speaks as a living invitation to seek God.

\section{Human Language Can Become a Way to God's Language}

In the beginning of linguistics we had difficulties with understanding man's capability for speech. Even though linguistic research first focused on discourse, nowadays the focus of research is on language itself. While the difference between a word and a discourse is somewhat understandable in this

21 Ibid., 80.

22 See E. Biemmi, Langage et langages en catéchèse. Problématique du Congrèes EEC 2012, Malta 2012, EEC Congrès (manuscript), p. 2.

${ }^{23}$ E. Biemmi, Langage et langages en catéchèse. Problématique du Congrèes EEC 2012, p. 3. 
area, the difference between speech and language, and language and discourse is much more difficult. Benveniste defines language as the fundamental characteristic of communication ${ }^{24}$, where the speaker inadvertently expects an answer. Man, Benveniste thinks, does not speak without a reason, the act of speaking predisposes that somebody had spoken to us first, taught us a word or understood a word, and thus responded to it in one way or another, and above all formed a living relationship with $\mathrm{us}^{25}$. In speech we use language, which is in itself a system of dynamic relationships of smaller parts and rules of connecting them. Everybody who enters in the process of communication must understand these rules for it to become a successful language. Language is meant for communication. "Language re-produces reality. This is to be understood in the most literal way: reality is produced anew by means of language. The speaker recreates the event and his experience of the event by his discourse" 26 . Human creativity, which is made possible by the nature of language, enters in this process of reproduction. If language is a dynamic system, with internal dynamic, we can approach one word with different points of view in this linguistic system. The richness of human language is in its diversity. A word can have one meaning, but in a system of usage get different twist or even a new meaning, which is again interpreted by man in a way that makes sense to him in a certain message.

A sign, which can be used by animals in their system of communication too, is clear in its meaning - it always carries the same message. A word, which is the most common sign in human language, is not constant. Man's aspiration for certainty and ultimately truth, is always searching for solutions to ambiguity of

${ }^{24}$ See E. Benveniste, Problems in general linguistic, Coral Gables 1971, University of Miami Press, p. 53.

${ }^{25}$ Ibid., p. 54. Benveniste, trying to explain the origin and uniqueness of the use of symbols in human language, compares it to the communications of bees' dance which they use to signal their beehive where food is located. He points out some key differences, which make him conclude that bee 'language' despite the fact that it carries a message, is not really communication and therefore is not a language at all, "This difference can be stated summarily in one phrase which seems to give the most appropriate definition of the manner of communication used by the bees; it is not a language but a signal code. All the characteristics of a code are present: the fixity of the subject matter, the invariability of the message, the relation to a single set of circumstances, the impossibility of separating the components of the message, and its unilateral transmission. Nevertheless, it is significant that this code, the only form of language found so far among animals, is the property of insects which live in a society. Society is likewise the condition of human language".

${ }^{26}$ Ibid., p. 22. 
human language. In doing this we could easily start simplifying the language. Legal language, as well as many other professional languages, strives for that because they need their own expressions to assure clarity of their specific communication. In a world, in which scientific language is being valued as the peak of human capability to approach the truth, it is difficult to place a language which would stay true to itself - enabling human communication. How is a man supposed to, with the whole scientific apparatus, express feelings of love, hatred, trust, doubt, is what Sesboüé27 asked himself - we need different styles of language for that. In the spirit of classical linguistic research the only language capable of this is human language. The spirit of technology and psychological understanding of man, in the sense of reflexive responding, changes even this genuine human language into 'autological'. "I mean hereby that here reality is no longer coming itself towards us with a meaning of its own, but that it is us who want to determine what, according to us with a meaning of its own, but that it is us who want to determine the norms of what we consider to be meaningful, or not. We ourselves want to determine what, according to us, can qualify to be meaningful, or not" ${ }^{\prime 28}$. With this autological approach to language, we are getting close to tautology, constant and ceaseless repetition of the same thing, emptiness of meaning, which we like to blame on religious language, and which more or less leads to the loss of faith in a living $\operatorname{God}^{29}$. This is especially obvious in the liturgy, where everything has to be understandable and pleasant, appropriate for participants, where we refer to so called natural experiences. Thus we less and less use biblical symbolism, signs, and stories, but instead we start with things that are more common to people - rock, butterfly, tree, stories

${ }^{27}$ See B. Sesboüé, Croire. Invitation à la foi catholique pour les femmes et les hommes du XXI. siècle, Paris 1999, Droguet \& Ardant, p. 60.

${ }^{28}$ I. Verhack, A plea for a language of welcoming and praise, Malta 2012, EEC Congrès (manuscript), p. 11.

${ }^{29}$ M. Buber, Božji mrk, Celje 2004, Mohorjeva družba, p. 14. Buber makes a similar conclusion, when he is discovering the reasons for absence of God and divine in today's world, "People, who are still 'religious' in times like these, mostly do not notice that what they consider a religious relationship does not happen between them and a reality which is independent from them anymore. Instead it is happening only within their own spirit, which contains independent images, independent 'ideas'. Then there appears, more or less obviously, a special group of people who consider this state legitimate. Never, is what they say, has religion been anything else than what happens within a soul, and which 'projects' its products on some made-up level that the soul somehow makes seem real...in the end, after he reaches a clear discovery, a man has to admit that the whole supposed conversation with the Divine was just a monologue, or more precisely, a conversation between different levels of being". 
from the world today, etc. "Their reason for doing so is that these symbols and texts would have a greater appeal to the young and to the people of today than the liturgical texts and symbols that would be 'difficult of access' and 'very remote of our life-world" 30 . Despite much effort and adaptation the churches are getting emptier. Not only that, but the religious is being replaced with secular religion - some sort of voyeurism, "The death of God did not just result in orphans, but also heirs. And in the eye of Big Brother it is not difficult to see the transposition of God's eye" 31 . Man who wanted to hide from God and then mistook God for his own experience is not satisfied by this. It is the language that 'gives him away' - what he used to hide from God ("we knew we were naked"), he now wants to reveal to everybody through the most viewed media. Even through this we can realize that language cannot be trapped in an idea or a concept. It is uncontrollable and cannot be instrumentalized. "On the contrary - it reveals that man lives for another, through relationships with others, planted in the history, which is ahead of him. Man lives and understands himself with the help of relationships and with language, through speaking and through what is being spoken to him"32.

Spiritual leaders are finding something similar. Even the seemingly very spiritual person, who admits his insignificance before God, is in danger of falling for autological thinking and consequently cannot advance spiritually. "He uses a form of dialogue, but only to knit a monologue. He cannot deepen a true relationship, cannot step out of himself but continues to do what he wills; he gives himself penance, betterment, missions, heroic deeds, good deeds, all of which is suggested by an ' $I$ "' 33 . Here we can remember concrete problems of many catechists and teachers, whose students do not listen to them. How can they listen if they do not understand what is being said to them. They live in their own world, which does not include communication ${ }^{34}$.

${ }^{30}$ I. Verhack, A plea for a language of welcoming and praise, Malta 2012, EEC Congrès (manuscript), p. 3.

${ }^{31}$ U. Galimberti, Grozljivi gost: nihilizem in mladi, Ljubljana 2009, Modrijan, p. 51.

${ }^{32} \mathrm{~S}$. Curro, La parole s'est faite chair... et la chair parle sur le langage religieux en relation avec la catéchèse, Malta 2012: EEC Congrès (manuscript), p. 8.

${ }_{33}$ M. I. Rupnik, Razločevanje, Ljubljana 2001, Župnijski urad Ljubljana-Dravlje, p. 91.

${ }^{34}$ See U. Galimberti, Grozljivi gost: nihilizem in mladi, Ljubljana 2009, Modrijan, p. 35. "The youth doesn't say 'we' anymore the way they said that in eighty-six (after the fall of an ideology they would say that less and less). They fled to a pseudonym of themselves and are obsessively repeating 'I', which is a small and limited space in an elevator". 
Shallowness, nihilism of the youth, inability to listen to something other than themselves doesn't only lead to a lack of religiosity, but also to a higher personal emptiness of individuals and a society. With the help of genesis of human language we can confirm that. Today, man is subconsciously convinced that he is his own beginning and the end. The fact that we cannot teach ourselves how to speak, and consequently how to think, is a reminder on one hand, and on the other hand gives us hope that we can still proclaim the truth, which transcends man. Vygotsky actually thinks that it is only through social speech, which is what Benveniste calls language, that egocentric speech can evolve ${ }^{35}$. If a child cannot develop social speech first, that is speak in communication with others, he or she cannot develop inner speech, which leads to spiritual and personal emptiness, shallownes ${ }^{36}$. A child and any human has to be first opened to listening and then to sensitivity with which they can accept the intentions of the speaker. The role of community is essential here. It is the same with teaching everyday language, "Vygotsky explains also that a child cannot reach ideal form in, for example speaking development at the end of a developmental level, without the environment that contains ideal forms. A child, who has just started speaking, says simple words and phrases, while his mother talks to him or her in a grammatically correct language, which includes a rich vocabulary, with the purpose for some of her speech to rub off on the child. The child is, not independently from mental capabilities, moving towards an ideal form of speech, which he or she could not have reached in a year or a year and a half by simple assimilation or copying. The problem arises if children do not have these ideal forms, for example deaf children with hearing parents. If there is only peer interaction present, the development is slow and can never reach a level that it could have reached had the environment contained ideal forms" ${ }^{\prime 37}$.

${ }^{35}$ See L. Vygotsky, Thought and Language, Cambridge 1986, The Massachusetts Institute of Technology, p. 35. "Egocentric speech, splintered off from general social speech, in time leads to inner speech, which serves both autistic and logical thinking".

${ }^{36}$ Vygotsky confirmed this experimentally, "After measiting the child's coefficient of egocentric speech in a situation similar to that of Piaget's experiments, we put him into a new situation: either with deaf-mute children or with children speaking a foreign language. In all other respects the setup remained the same. The coefficient of egocentric speech dropped to zero in the majority of cases, and in the rest to one-eighth of the previous figure, on the average". L. Vygotsky, Thinking and Speaking, (http://www.marxists.org/archive/vygotsky/works/words/vygotsky.htm).

${ }^{37}$ L. Marjanovič Umek, Pojmovanje otroka v sociokulturni teoriji Vigotskega, and: L. Vigotski, Mišljenje in govor, Ljubljana 2010, Pedagoška fakulteta, p. 381. 
Inclusion of many dimensions of language, as are discovered by linguists and as are used by Vygotsky, is also demanded by the nature of Divine pedagogic. Despite limitations of human experience, the voice about God has to cross the everyday experience of human relationships. We must talk not so much about concepts of faith, but about a relationship with a real person: Christ. Man can understand internally before he can conceptually master a certain topic. Like a child, who uses words that he doesn't know the real meaning of yet; in the same way every one of us can talk about the 'unimaginable', and consequently think about it and create ideas about it. It is therefore possible for him to move from inability to speak about something on a higher conceptual level, he just needs stimulation and some example (we can say evangelization) from outside. A community hands on such evangelization and encourages, with its inner dynamics, individuals to pass it on.

\section{Evangelization, Which Speaks to Us: Community}

Even though modern man does not like to hear the word evangelization, the basic expectations of catechetic work are, "Catechesis will always draw its content from the living source of the word of God transmitted in Tradition and the Scriptures, for sacred Tradition and sacred Scripture make up a single sacred deposit of the word of God, which is entrusted to the Church" 38 . If we carefully read the quoted text, we must consider the word 'living'. The nature of revelation in Scriptures is always historical, dependent on events and concrete people; it is a living word, expressed in a language of living people. “The Word of God, by wondrous divine „condescension” is directed toward us and reaches us by means of human „,deeds and words”, ,just as the Word of the eternal Father, when he took on himself the flesh of human weakness, became like men". And so without ceasing to be the word of God, it is expressed in human words"39. Priority of life over teaching is obvious already in the Scriptures; especially if we consider the idea of love in the New Testament, which is a foundation of understanding any God's message. The Bible is connected to events which are the reason for its content; these events are preserved in the Bible in order to trigger new events, which will

\footnotetext{
${ }^{38}$ General directory for catechesis, 94.

${ }^{39}$ General directory for catechesis, 94.
} 
continue the first ones with the power of remembrance and repetition. It is only if Revelation becomes a real-life event that we can count on modern man to listen to it, and for it to become a new beginning in his life - encounter of God and $\operatorname{man}^{40}$. It can only be real for a concrete man in a concrete situation. Above all, it has to be an event of encounter with another, different, Revealed, and not just affirmation of oneself, and worshipping and maintaining an idol that was created in one's own image.

The fundamental condition for this is to revive a sense for another, and create room for truth, which at first glance is not 'mine', but is rooted deeper within us than we can ever imagine. We must return from 'cogito, ergo sum' to 'respondeo, ergo sum' (I respond, therefore I am) ${ }^{41}$. "From the methodological point of view, this means that we will have to make a transition from autology to dectology. 'Dekton' is the Greek word for 'that what is being received"' We must return to a discovery, or better way of living, that our life was given to us, that our language, which we use to express and name ourselves with, has preceded us; to a theology of a gift. If our culture is a culture of seen, useful, tangible, and it requires ultimate realization of an individual, then the fundamental, that which can fulfill a man, is invisible. Even though this 'never heard' comes from within us, it points us outward, because it is only through a relationship with another, a different individual, that we realize that we are a subject who fights against becoming an object ${ }^{43}$. It is this lack of clarity of our own meaning that is the most clearly seen in language. As Benveniste finds out, human language does not bring certainty, but inability to capture different meanings; the same thing happens in understanding oneself in the process of communication. Which is the best experience of transcendence within immanence.

${ }^{40}$ See H. Mend1, Religion erleben, München 2008, Kösel-Verlag, p. 43.

${ }^{41}$ See U. Galimberti, Grozljivi gost: nihilizem in mladi, Ljubljana 2009, Modrijan, p. 91. When he describes the origins of nihilism in youth today, he concludes, "All these factors prepare a fertile ground for loneliness; this is not despair that attacks those who used to have hope, but it some sort of 'zero gravity' of those who find society as a useless space. There is no use in sending messages into this space, because there is nobody to receive them, and a possible call for help would be simply returned by an echo".

${ }^{42}$ I. Verhack, A plea for a language of welcoming and praise, Malta 2012, EEC Congrès (manuscript), p. 12.

${ }^{43}$ See S. Curro, La parole s'est faite chair... et la chair parle sur le langage religieux en relation avec la catéchèse, Malta 2012: EEC Congrès (manuscript), p. 9. 
Something is certain in this world - a desire to be somebody in one way or another. In this deep, selfish desire to be accepted as a subject, a person by other people, we can find the essential starting point for opening to Revelation. Ricoeur finds three experiences that can open a man to a capability of seeing others as himself. He calls them experiences of passiveness. "First there is passiveness, contained in the experience of one's own body, or as we will call it later, flesh, working as a mediator between oneself and the world itself, which is perceived according to its variable levels of usefulness and therefore alterity. Next there is passiveness, implicated in a relationship between oneself and alter, exactly in the meaning of being different than oneself, as it were, otherness, which belongs to a relationship of intersubjectivity. Finally, there is the most concealed passiveness, passiveness of oneself in relation to oneself, which is conscience, more so in the meaning of Gewissen than Bewusstsein. By putting conscience as a third passiveness in relation to passiveness-alterity of own body and passiveness of another, we stressed the extreme complexity and relational density of meta-category of alterity" ${ }^{\prime 4}$. If we want this conflict of triple passiveness-alterity to evoke a need to create one's own conscience, which would include a need for being a someone in relation to another (other than oneself), we have to first build openness for truth, and not only for understanding oneself ${ }^{45}$. This need has to include what is given, 'outer', alterity of the body, another, and conscience, which can be felt as such, because it is often in conflict with our own desires. Without the fundamental desire for being, and being good in relation to another, we cannot come to think and act in a way that is worthy of a subject. All of this is not possible without a relationship, which can only be achieved in a community.

What Ricoeur accepts as the goal of all our desires, cannot exist without accepting feelings for another, a feeling of passiveness in oneself, first one's own body, then other people, both intertwined with one's own conscience. In the subject, which experiences himself this way, is the real truth, which will answer his deepest desires for being, a discovery that he is not his own beginning, let alone ending, it is unconditional and inherent desire for redeemed life. If we want to avoid nihilism and pessimism of modern

${ }^{44}$ P. Ricoeur, Soi-même comme un autre, Paris 1990, Seuil, p. 369.

${ }^{45}$ To plant God's seeds, one has to first prepare the soil, concludes J. Gallagher in his book, which sets a plan for modern evangelization. See J. Gallagher, Soil for the Seed, Great Wakering 2001, McCrimmon. 
sociologists and anthropologists, we need community for this process of 'growing up'; a community that will nurture a kind of humility of alterity within itself, it will nurture a conscience through its very nature - by not being its own source, but being a gift - being funded by a free gift ${ }^{46}$. That this is a correct step is confirmed by linguistic theories, since languages, and according to Vygotsky thoughts also, are not possible without a community. The Church, as the mysterious body of Christ, which is unceasingly connected to the upcoming Kingdom of God, is the appropriate answer to this need.

Man is thus not afraid to listen to himself and the community, which accepts his body (the role and power of sacraments), connection to others (dimension of charity), and his own conscience (the place of sin and forgiveness). The Church does all this knowing that every person in God's gift to us all. This way we connect man's selfishness and his need for acknowledgment. Through wonder, which comes from knowing that something transcends us, something that precedes us and is independent from us, which we can discover as something that is non-transparent to myself, we become open to acknowledging quality of life outside of ourselves. "When this condition is respected, something new ,opens up' and comes towards us in the ,open' of this encounter: a new dimension of being and being-human which we can only open ourselves to and that falls to our share of grace. It is the dimension of being-beyond-oneself and of being-there-for-the-other" ${ }^{\prime 4}$.

The shortest way to another, and the truth that we want to hear about ourselves, comes through the power of giving in to this feeling of exposure and accept this as the foundation of our being ${ }^{48}$. Evangelization has to

46 "The mystery of the holy Church is manifest in its very foundation. The Lord Jesus set it on its course by preaching the Good News, that is, the coming of the Kingdom of God, which, for centuries, had been promised in the Scriptures: "The time is fulfilled, and the kingdom of God is at hand". In the word, in the works, and in the presence of Christ, this kingdom was clearly open to the view of men. The Word of the Lord is compared to a seed which is sown in a field; those who hear the Word with faith and become part of the little flock of Christ, have received the Kingdom itself. Then, by its own power the seed sprouts and grows until harvest time". Lumen Gentium (Dogmatic Constitution on the Church), 5.

${ }^{47}$ I. Verhack, A plea for a language of welcoming and praise, Malta 2012, EEC Congrès (manuscript), p. 16.

${ }^{48}$ See L. Boeve, Beyond correlation strategies, in: H. Lombaerts and D. Pollefeyt (ed.), Hermeneutics and Religious Education, Leuven: Leuven University Press, p. 252. "This is clearly the case for pupils who not only become aware of plurality and the otherness which it serves to illuminate, but who also actively learn to deal with plurality in the formation of their own identity and in the clarification and elaboration of their own fundamental life option(s). Pupils are challenged 
originate from this exposure to real life of an individual and the community, in sin as well as virtue, strength as well as weakness, pain as well as pleasure. We must learn to touch all of these, see them and talk about them, because the 'exposed' being is necessary for a real encounter with the Word, which is only possible in a vibrant community. Just as Christ built the community without expectations, since he chose his apostles from the just as well as unjust, faithful and unfaithful, but at the same time maintained an open conversation, "But who do you say I am?"49, so is our Church called to create a social space, which will in Vygotsky's way offer a purpose that the world cannot give us, and at the same time enable all its members to cry, just like St. Thomas, "You are my Lord and my God!"50. This will be the closest we can get to mandates of General directory for catechesis, "In transmitting faith and new life, the Church acts as a mother for mankind who begets children conceived by the power of the Spirit and born of God. Precisely „because she is a mother, she is also the educator of our faith"; she is at the same time mother and teacher. Through catechesis she feeds her children with her own faith and incorporates them as members into the ecclesial family. As a good mother she gives them the Gospel in all its authenticity and purity as apposite food, culturally enriched and a response to the deepest aspirations of the human heart" ${ }^{\prime \prime}$.

\section{Bibliography}

Benveniste E., Problems in general linguistic, Coral Gables 1971, University of Miami Press.

Biemmi E., Langage et langages en catéchèse. Problématique du Congrèes EEC 2012, Malta 2012, EEC Congrès (manuscript).

Boeve L., Beyond correlation strategies, in: H. Lombaerts in D. Pollefeyt (ed.), Hermeneutics and Religious Education, p. 233-254, Leuven 2004, Leuven University Press.

Buber M., Božji mrk, Celje 2004, Mohorjeva družba.

Curro S., La parole s'est faite chair... et la chair parle sur le langage religieux en relation avec la catéchèse, Malta 2012: EEC Congrès (manuscript).

to discover plurality and otherness, and learn the communicative attitudes and capacities necessary for living in this plurality".

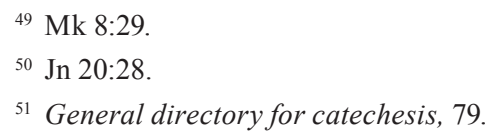


Dillen A., Pollefeyt D., Catechesis Inside Out. A Hermeneutical Model for Catechesis in Parishes, "The Person and the Challenges" 1 (2011) 1, p. 151-177.

Ferry L., L'Homme-Dieu, Paris 1996, Grasset \& Fasquelle.

Galimberti U., Grozljivi gost: nihilizem in mladi, Ljubljana 2009, Modrijan.

Gallagher J., Soil for the Seed, Great Wakering 2001, McCrimmon.

General directory for catechesis, http://www.vatican.va/roman_curia/congregations/ cclergy/documents/rc_con_ccatheduc_doc_17041998_directory-for-catechesis_en.html (08.07.2012).

Lombaerts H. and Pollefeyt D., The Emergence of Hermeneutics in Religious Education Theories: An Overview, in: H. Lombaerts in: D. Pollefeyt (ed.), Hermeneutics and Religious Education, p. 3-53, Leuven 2004, Leuven University Press.

Marjanovič Umek L., Pojmovanje otroka v sociokulturni teoriji Vigotskega, in: L. Vigotski, Mišljenje in govor, Ljubljana 2010, Pedagoška fakulteta, p. 373- 400.

Mendl H., Religion erleben, München 2008, Kösel-Verlag.

Nord W.A., Does God make a difference?, Oxford 2010, Oxford University Press.

Die österreichischen Bischöfe, Verkündigung und neue Evangelisierung in der Welt von heute, Wien 2012.

Ganzheitliche Methoden im Religionsunterricht, L. Rendle (ed.), München 2007, KöselVerlag.

Ricoeur P., Soi-même comme un autre, Paris 1990, Seuil.

Rupnik M.I., Razločevanje, Ljubljana 2001, Župnijski urad Ljubljana-Dravlje.

Sartre J.P., Izbrani filozofski spisi, Ljubljana 1968, Cankarjeva založba.

Sesboüé B., Croire. Invitation à la foi catholique pour les femmes et les hommes du XXI. siècle, Paris 1999, Droguet \& Ardant.

Verhack I., A plea for a language of welcoming and praise, Malta 2012, EEC Congrès (manuscript).

Vygotsky L., Thinking and speaking, http://www.marxists.org/archive/vygotsky/works/ words/vygotsky.htm (07.07.2012).

Vygotsky L., Thought and Language, Cambrige 1986, The Massachusetts Institute of Technology. 